\title{
Ageing and the Welfare State: A Theory of Risk Jason L. Powell
}

\author{
Department of Social and Political Science, \\ University of Chester, CH1 4BJ, United Kingdom \\ E-mail address: Jasonpwll3@gmail.com
}

Keywords: ageing; welfare; state; theory; risk

\section{ABSTRACT}

How do we define "old age"? Is it a stage in life defined by a particular age event su as retirement, is it determined by physical characteristics and the loss of in opunden or is at an artifact of social structures? Indeed, is it helpful to categorize people as bei o "old all, as opposed to being "disadvantaged" or "dependent"? It may be inaccura ex ect or people to see themselves as a category with particular health needs and yants.He the $1, y$ task is to analyse the interplay between social policy and the lives of ip iduals, fas or groups and communities. The expectation of negative events in the futu ano differe st ways of how to respond to such expectations is central for the sociological proach is and uncertainty (Zinn 2004). Part of this reflexive response is the importance o recognising sel abjective dimensions of emotions, trust, biographical knowledge and resources Zinn 2005) that impinge on the existential shaping old age. Hence, our discussion provides a critic narrative $t$ the importance to the study of old age and welfarism in America and Europe.

\section{INTRODUCTION}

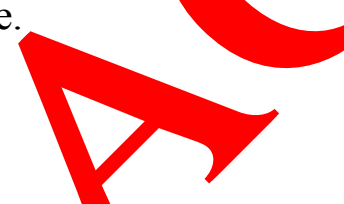

This article explores the ceept 'risk' it relation to the theoretical study of old age and welfare in North America and uro with what has been conceptualised as the 'risk society' (Beck, 1992) have, might bu vued, become part of the foundation of how we define and position the 'personal' a cial spao in which to grow old. This has startling continuities across Europe. These s, aces served to place the definition of what it means to be an older person - shifts fron state care to ividualised care (Phillipson and Powell, 2004). As Ulrich Beck (1992) claims, in the co ditions of advanced modernity, growing old moves from being a collective to an individual er ence a d responsibility. Further, Anthony Giddens (1998) suggests that old age is a social cons ted ca cgory shaped in 'late modernity' by its politically pioneered definition in terms of in ement.

'Old ago stary is is a creation, pure and simple, of the welfare state. It is a form of welfare dependency ch more widespread than any of the dependencies noted by the rightist interpreters of the underc, os (1994:170). [And]:- A society that separates older people from the majority in a retirement ghetto cannot be called inclusive' (Giddens, 1998:120).

However, Giddens claims that risk is an important factor in the reflexive shaping of old age. First, it is claimed that traditional responses to risk are no longer appropriate. Second, and a key factor highlighting the point above, European societies are themselves less predictable. Faith in the ability of the State or scientific experts to manage risk on our behalf has therefore diminished. Third, people must anticipate and address risk. Whether this is best achieved by collectively sharing the responsibilities that may lead to individualisation. Four, traditional definitions of risk, premised on technical measures, neglect the social construction of these and of the risks themselves. This in turn poses fundamental questions about the way we define old age. By representing risk as a 
centrally defining discourse of "late modernity" offers a new perspective: it allows the interrogation of how older people are made subjects in Europe (Powell and Phillipson, 2004).

Foremost in American and European societies with little developed welfare systems the concerns regarding the side effects of a society governed by the concepts of risk and individualisation are widely disseminated (Giddens, 1991). Linked to this, neo-liberalism gives the impression that older people have the capacity to generate their own autonomy and responsibility as indicative of 'consumer culture' (Gilleard and Higgs, 2000) irrespective of structural constraints. Similarly, theorists advocating positive ageing pontificate from a cultural approach by focusing on the benefits of neo-liberalism (Gilleard and Higgs, 2000). This is particularly apparent in a move toward neo-liberal discourses of consumerism which artificially appears to indicate a realloation of attention from responding to problems such as 'poverty' (cf. Walker, 1981), for examp. an attempt to define what it is to allegedly 'age positively' in an neo-liberal era ve older p ple "have never had it so good" (Gilleard and Higgs, 2000). For Gilleard and Hig s (20 this tre d is happening in western culture and greatly reconstructs both the formal ey pectations pe sonal experiences of later life. Interestingly, Gilleard and Higgs $(2000 ; 2005)$ not s the re vance of risk to the uncertain postmodern times through which older people xp cheir p formativity. Whilst such a neo-liberal account is highly idealistic it does not hi hlight th stor an features of everyday life of older people and the impingement on ris 1 h an aco it represents an ideological distortion by not focusing on the uneven distrib ons ower across America and Europe for older people- such neo-conservative writers or frock the rish ardship and poverty in old age Indeed, Alan Walker and Gerhard Naegele (199 ) convey the critial message that there is a pressing need for governments and other agencies t respond to thanging circumstances of an ageing European population. European political proces have bec me preoccupied with the fiscal support of the delivery of social services to an oceing pop s this demographic shift alters the balance between those in work and paying ta those in retirement receiving benefits and consuming health care and other social services. Cor sum theorists such as Gilleard and Higgs (2000) overlook and underemphasize the risks tached the structural positioning of old age in Europe. The historical lesson is ths. oughou the 1980s and 1990s European governments uniformly sought to introduce ne delivery of services by creating quasimarkets that rely on internal mu purchasing by providers. In the United Kingdom for example, legislation re ired that authorities embark upon a phased program, directed by central government, of omp ory comp utive tendering, with the strategy of decreasing the role of local authorities ar sumula oreater provision of services by the private sector. This program, like its cousins elo $c$ where on the conent such as France and Germany, rested on the belief that a competitive ma and yixed economy of welfare inevitably provides services that are better and cheaper than thos ailable rough the public sector, the reasoning being that a protected public bureaucra capab nly of furnishing services that are limited, inflexible, and indeterminate and many ers a unable obtain the services they require. European governments assume that they

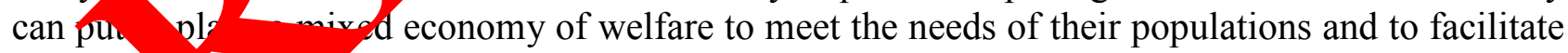
consumer vice among the various services. However, the introduction of "choice" may in fact reduce the in of options available because a reduction in public sector provision may not be matched by the development of a diverse range of service options in the voluntary and private sector (Powell and Phillipson, 2004). Planning is necessary, particularly in light of the demographic changes. The statistical reality that Europe's population must inevitably age because the fertility boom in the late 1950s and early 1960s and the increasing expected average lifespan will greatly increase the number of older persons across the European Union from about 2020 forward. The spectre of an ageing population necessitates the dismantling of the welfare state and the introduction of a greater degree of reliance on personal financial provision and privately provided care arrangements. These proposals are linked to ideological shifts during the latter part of the twentieth century, and the concomitant reassessment of the social contract between the state and its population. As a result, "cradle-to-grave" principles of postwar social planning have been replaced 
by policies which encourage those with resources to make provision for themselves, with the less well off depending on minimal state support. This exclusion has serious implications for the workings of EU states, for over time the issues raised will test the stability and security of health and political structures in all European countries. In order to preserve the basic tenets of intergenerational solidarity and to develop a more inclusive society, it will be necessary to find ways in which the views of older people can be appropriately represented (Powell and Phillipson, 2004). Older citizens must have a greater "voice" in the decision-making process of welfare services provision. The point made by Walker and Naegelhe (1999) is abold one that a new political economy of ageing is needed to engender social policy that rests on a broader view of what older persons need and the manner in which they can contribute to and make a different society, rather than the current policies that focus alone on pension arrangements and the provision social welfare. New policies are needed to meet the requirements of the risk society. Th politio fold age is not just about learning to live with an older population and how to arrane he provis of services, but is more about rethinking the nature of European society itself.

Indeed, in contemporary European society, risk is a broad concept that nds over by oad range of social practices that impinge on the experiences of older peopl Sur debate about older people and relationship to sexuality, crime, national security, foo afety, em are all underscored by risk (Phillipson, 1998). Moreover, there s gi ing recogy tion that potential risks of the future that transcends EU States - 'global warm 'gene cloning', 'GM foods' and 'bio-terrorism' - shatter the rigid boundaries of nations a a demand globa $\mathcal{O}$-operation and control. Awareness of the trans-national nature of risk has ed the United Nations to form its own Commission on Human Security. A recent report by t UN Comn ission suggests ways in which the security of older people, for example, might be a aced - rom humanitarian and military strategies through to economic, health and ational sumugies. Whilst 'freedom from want' continues to be the most pressing global imper '1vo, acent years 'freedom from fear' has risen up the global political agenda (Commission on Iy han ycurity, 2003, 4). Coupled with this, the US Central Intelligence Agency's (200 World Fact Book suggests that an "ageing population" is a risk to the financi safet of weste nation states in US and Europe.

\section{NEED MORE M TRIAL O TK, AGEING IN USA}

In science, rick as tr. ionally been approached as an objective material entity, to be mastered by proce os of calcula assessment and probability. In the $21^{\text {st }}$ century, 'advances' in science and mer cine lo to the eydication of many infectious diseases, raised life expectancy in old age and imp. quality of life across Europe. The nature of scientific knowledge about risk and impact agen as aculated the perspective that as a person goes through aging process there ar hel ened $r$ lo the human body - in the mind and internal organs of the body. It has grada bec me clea that the very institutions entrusted with regulating risks have themselves transmut nto mon producers. In recent times, multinational corporate business, science, medicine and govern thave all been accused of generating various dangers to public health which impinges on ti - safety of older people.

In response to public concerns about unbounded techno-scientific development and the apparent inefficacy of expert systems, interest in risk has gathered momentum within social science disciplines in recent years (cf. Giddens, 1991). However, whilst the language of risk has become prolific, the concept itself remains cloaked in ambiguity and its relationship to ageing scantily researched; making risk and ageing an important and significant issue for social policy. Yet, it is under theorised and reified in its conceptualisation. 
Such an approach seeks to capture the dimensions of subjectivity within the social-political constraints that shape individual lives. This allows reconstructions of logics of action or structuration behind current neo-liberal self-representations of ageing identity. It could be supposed that such constructions enable us to reconstruct the complexity of ageing in social contexts and the influence of, for example, social welfare on these experiences as a ground for risk perception. Importantly, the notion of an ageing society becomes secondary to the emphasis on the way in which families and individuals handle the demands associated with an ageing population. Phillipson and Powell $(2004,33)$ suggest that there are three factors that make risk important to understanding old age:

'First, the globalisation of aging is increasingly recognised. All societies (poor as well undergoing similar population transformations (albeit with notable exceptions sy as in countries devastated by the AIDS virus). Aging thus becomes simultaneously b a biograt cal event and one shared with different cultures and societies across the obe. cond, sing experiences are themselves hugely (and increasingly) diverse. Under the gase of the fare state, growing old was compressed into a fairly limited range of institution nd id ities ably in respect of income and lifestyles). Aging in the post-welfare societ ho Lr, has ibstantially expanded in respect of social opportunities as well as economic in qualities. $\mathrm{r}$.r., ld age is also being changed by what Beck (1992) describes as the era of re le. moderni. on. This may be conceived in terms of how individuals and the lay public exa conth vind influence on the shape and character of modernity.'

The more American and European societies ar hodernised the more older people acquire the ability to reflect upon the social forces of thei istence within the conditions of risk constraints. Hence, we need to understand the ior sociaryures which impinge on ageing itself. Such social forces that create risk associated itring implies a breakdown in trust as a key modernist principle in contemporary society. $\mathrm{H} \mathrm{p}$ e, thy rest of the article is in three parts: we introduce the relevance and breakd in trust elations; map out the key assumptions of risk society in Europe; and critically e rage th old a and examples drawn from social welfarism to consolidate an understanding of the no old age in Europe.

\section{FROM TRUST TO}

There are creasing atter to conceptualize the notion of 'trust' in social theory as a pivotal dimensi of El pean socrety (Giddens, 1991). However, the early statement that 'social science research ast has coduced a good deal of conceptual confusion regarding the meaning of trust an place socio, Mife' (Lewis and Weigert 1985 quoted in Powell, 2005, 104) seems to be still valid peciall, applied to aging studies. Trust is on the one hand incompatible with compr ign of the possibility and probability of future events, and on the other hand with emphatic ef wnen the anticipation of disappointment is excluded. Someone who trusts has an expectation agted to an event. The expectations are based on the ground of incomplete knowledge $a b$, ut the probability and incomplete control about the occurrence of the event. Trust is of relevance for action and has consequences for the trusting agent if trust is confirmed or disappointed. Thus, trust is connected with risk (Giddens, 1991).

Up to now there have been few attempts to work out a systematic scheme of different forms of trust in between older people and individuals, institutions or policies that impinge on their identity performance. Social trust tends to be high among older people who believe that their public safety is high (Walker and Naegele 1999). Since the erosion of public trust in institutions such as, for example, the Brown government in UK with it losing 25 million people's bank details and identity or the $£ 25$ billion financial loss of UK bank Northern Rock in late 2007, 'trust' has attracted more and more attention. 
Molling (2001) distinguishes between trust in contracts between people and State (such as pension provision), trust in friendships across intergenerational lines, trust in love and relationships and trust in foreign issues (associated with national identity across the EU). However, sociological theories which suppose a general change in modernity (cf. Beck, 1992) assume that with the erosion of traditional institutions and scientific knowledge trust becomes an issue more often produced actively by individuals than institutionally guaranteed.

There are a number of implications of risk perception and risk taking that indicates: trust is much easier to destroy than to built; if trust is once undermined it is more difficult to restore it; familiarity with a place, a situation or a person produces trust; persons will develop trust if a person or situation has ascriptive characteristics positively valued. Trust seems to be something that is produced individually by experience and over time and cannot be immediately and with munose be produced by European governments without dialogical interaction with older pople on sues affecting their lifestyles and life-chances such as care, pensions, employp and po cal representation in the EU (Walker and Naeghele, 2000). Though as Giddens (991) vesses $r$ is the feature of a society shifting its emphasis away from trust on tradition / ties and al alues. How risks are perceived and formulated as a breakdown in trust reflect the es tially scursive practices of politics and power in European society. The ability to co ro manag perceptions about moral intentions of a pervasive governmental rationality $\mathrm{m} z$ be part $n$ un cerstanding of risk.

\section{BECK AND THE 'RISK SOCIETY' THESI'}

The concept of risk has come to assume accele ing promin nce in sociological writings of Ulrich Beck. Beck (1992) claims that modernization $h$ the self become an agent via processes of individualization which they both see as in icative of alism; they advocate that the self become less constrained by traditional group 1 and institutions but more constraint by the dynamics of markets (labour markets, consume makcund secondary institutions, and becomes therefore a project to be reflexively warked on in the context of a globalised world. As we see the development of this the new global orde ome ris such as those caused by hazardous industries, are transferred away from the $\mathrm{d}$ aped countries to the Third world. Thus while Beck sees risk society as a catastrophic soc w we and the theing is the thence of certain risks through aversion and management 'bich in tu. 'nclude a reorganisation of power and authority' (Beck, 1982:4)

Beck ackn wledoes that so social groups are more affected than others by the distribution and growth of $r$, and ese differences may be structured through inequalities of class and social position. The dis antaged have fewer opportunities to avoid risk because of their lack of resources thared advantaged. By contrast, the wealthy to a degree (income, power or educat n), cà purchas afety and freedom from risk (Beck 1992: 33). However, it is the gestation and th on the risks, which are unknown, and thus risk affects those who have produced profited from them, breaking down the previous social and geographic boundaries evident in m societies.

Beck (1992), argues that the 'former colonies' of the western world are soon becoming the waste dumps of the world for toxic and nuclear wastes produced by more privileged countries. Risks have become more and more difficult to calculate and control. Hence it can be argued that Risks often affect both the wealthy and poor alike: 'poverty is hierarchic and smog is democratic' (Beck, 1992: 36). At the same time, because of the degree of interdependence of the highly specialised agents of modernisation in business, agriculture, the law and politics, there is no single agent responsible for any risk: 'there is a general complicity, and the complicity is matched by a general lack of responsibility. Everyone is cause and effect' (:33) and so 'perpetrator and victim become identical' (:38) in a consuming society. It is this immateriality and invisibility of the threats 
that saturate the 'risk society' making it harder to identify the offender of global risk. Beck (1992), argues that this fundamentally poses the second challenge for analyses of these socially constituted industrial phenomena: interpretation becomes inherently a matter of perspective and hence political. Politicians constantly invoke science in their attempts to persuade the public that their policies and products are safe. The inescapability of interpretation makes risks infinitely malleable and, as Beck (1992:23) insists, 'open to social definition and construction'. This in turn put those in a position to define (and /or legitimate) risks - the mass media, scientists, politicians and the legal profession - in key social positions (Phillipson and Powell, 2004).

Ulrich Beck (1996) makes the point that risk is not an option which could be chosen or rejected in the course of political debate' (1996:28). Instead this is an inescapable numpt and structural condition of advance industrialisation of where we produce the hazards $\rho^{f}$ that $s y$, in Beck's words (1996:31)'undermine and/or cancel the established safety system f the pro ent state's existing risk calculation'. Beck (1996) further exemplifies this oin exam ing contemporary hazards associated with nuclear power, chemical pollution and genetio gin ering and bio technology that cannot be limited or contained to particular $\mathrm{sp}_{\mathrm{s}} \mathrm{s}$, and at wh cannot be grasped through the rules of causality, and cannot be safeguar ad, "pensate or insured against. They are therefore 'glocal': both local and global. Ris' society 'hus curopean risk society' and risks affect a European citizenship. The questionip he outcon of modernity in terms of their production of risks is an outcome of reflexive indern ion. An awareness of risk, therefore, is heightened at the level of the everyday.

In both North America and Europe, risk, in its rely technic al meaning, came to rely upon conditions in which the probability estimates of an ev are able $o$ be known or knowable. This has the effect of paralysing action and bringing insu stems that promised to cover eventualities into chaos. In Great Britain for the welfare state, an insurance system that promised to cater for people from cradle to the rave to sustain that promise for future generations. The welfare system as a suctem of s cial insurance is beginning to lose its legitimacy with the rise of private health insy ance In the SA, 70\% of its population do not have private health insurance (Powell and Phi on, 004).

Scientists have lost eir authon in relation to risk assessments most evidently seen in the collapse of endowment nd ain pensi funds. Scientific calculations are challenged more and more by political gre psand a ists. (Beck 1995:125-6). The nature of such hazards, therefore, returns the concer of risk to the -modern notion of 'incalcuble insecurities'. In common with such hazards, th 'und the social logic of risk calculation and provision' (Beck 1995:77). For Beck, then, risk n. e defin as 'systematic way of dealing with hazards and insecurities induced and introd by m rnis cion itself' (Beck 1991:21).

If this be respon. "e for the growing risk awareness in modern industrialised societies in Europe, even though thein cective contribution is contested. The new awareness of the limits of the technical and the mathematical/statistical calculation of risk would cause an increase of concerns regarding the rational controllability of an uncertain future (Beck 1992, Bonß 1995). Furthermore, the sustained endeavour to apply a new liberal style of governing modern societies would increasingly shift the responsibility of the management of risks and uncertainties from the state to the individual . Socio-demographic changes as well as shifts in governance contribute to the perception of risk and uncertainty regarding old age in two ways: First, they promote the understanding of risk and uncertainty in old age and second, they suggest to perceive age as risky and uncertain.

In order to approach the concept of risk and old age it is suggested that by conceptualising risk in a broader framework of (un-)certainty (Zinn 2005) where risk is seen as a specific strategy to 
produce certainty in order to enable to act. Risk appears then as a certainty construction - a specific way to produce the necessary certainty as a prerequisite for action (Zinn 2004). Thereby the future becomes accessible for planning and action. In order to work on itself, the 'self' or at least according to Beck $(1992,181)$ relates to self-political rationalities and risk: 'risks become the motor of self-politicization of modernity in industrial society'. One element of the 'motor' of selfpoliticisation is how successful neo-liberalism has been in fashioning common sense discourses around its political rhetoric. Jurgen Habermas (1986, 13-14) claims what we are witnessing is a 'completely altered relationship between autonomous and self-organized public spheres on the one hand, and sub-systems steered by money and administrative power on the other'. Selfautonomization coupled with administrative power is indicative of 'risk': neo-liberal features of social policy for older people. Older people living in neo-liberal EU societies have therefmamoved towards a greater awareness of risk and are forced to deal with risks on an veryda, asis: 'Everyone is caught up in defensive battles of various types anticipating the ho substan in one's manner of living and eating' (Beck, 1994: 45). The media for thei par ve take up warnings of experts about risk and communicate them to their mass publics in the EU.

There is an ambivalence at the heart of Europe: on the one hand, old po are to 'managed' by other administrative powers such as professional experts in $\mathrm{m}$ dernity (A ell ald Phillipson, 2004); on the other hand, older people are left to govern them en This mo idea of freedom and responsibility is involved in the modern notion to govern Europ societies (Foucault 1991) but is determined by the limits of everyday life in sociocu curaty differe icumstances (Bourdieu 1979) within a 'risk society' (Beck, 1992). The tension between ideal and socio-cultural structured life constitutes the battleground of the disputes on the vernance of old age. These, along with ties between generations, created a social, economic and mo space win which growing numbers of older people could be channelled and contairad. For ex. or a period of 20 years or more, moving older people into the zone of retireme welfare state, held at bay the underlying issue of securing a place and identity for agein w wh framework of an advanced capitalist society. The meaning of later life was - temporan a least, constructed out of a modernist vision where retirement and welfare were new as natur lend-points to the human life cycle.

\section{THE GOVERNANC OF NTY IN WELFARE AND OLD AGE}

The governance of age orig $1 \mathrm{v}$ developed and was closely linked to the creation of a social security system a d th elfare sta $\int$. The idea of prudence and self-responsibility among the working class was grussed i. "gh, such institutions as the friendly society and the revolving building society a promoted bo political quiescence and the stability needed to ensure steady growth in the or ha of the $19^{\text {th }}$ century (Dean 1999). This system was supplanted by the development of $\mathrm{h}$ ance in he $20^{\text {th }}$ century leading to the modern welfare state (Ewald 1986, O'Malley Tho ovion for old age was originally not central, because at the end of the $19^{\text {th }}$ centur most cople div ot reach the age of 70 to claim a pension and live through this last phase of then foring to work. The original concept was to save the worker and its family in case of de. or disablement of the breadwinner.

The stategies of risk-management by means of insurance were understood as sharing them between all insured people, which should be in principle as much as possible. But this fundamental concept has changed recently as part of a general change in the idea of insurance as well as the government of citizens. The responsibility of the state and thereby the risks are given back to the public. As Baker and Simon $(2002,4)$ recently pointed out, “...private pensions, annuities, and life insurance are engaged in an historic shift of investment risk from broad pools (the classic structure of risk spreading through insurance) to individual (middle-class) consumers and employees in return for the possibility of greater return."

The understanding of the individual as a self-responsible actor as given for granted underestimates the various resources and life experiences different people possess. The strategies to 
cope with risk and uncertainty in the life course are rather oriented on the circumstances of everyday life, personal values and life experiences that relate to self-responsibility. Governmental programmes are mainly developed against the background of the model of a self-responsible actor, and increasingly address people with significant lack of cultural and economic resources as selfreflexive and rational actors (Taylor-Gooby 2006). Although this concept might be generally helpful in order to formulate political programmes they regularly fail because of this assumption.

The governmental constructions of risks and old age converge in the notion of rational acting old people. It does conceptually ignore that the ability to be autonomous and rational is not a question of context-independent (free) will or something what is just given, but it is provided by context factors as well as biographical experiences which shape expectations regarding the future. Thereby accumulated "local knowledge" (Wynne 1996) produces logics of how to act hast in an uncertain context (e.g. Zinn 2005), which include the policy of the government as rell. Th not only important when people are old, but in earlier life phases when they have deal with heir expectations regarding old age and have to take precautionary measures. The un al reso ces available, the unreflected routines and the needs and execution of everyd $y$ life shap hat is the basis to act in 'old age' (Powell and Phillipson, 2004).

The extrication of these actions can be traced to at least ty the types affecting the management of aging populations in the last quarter of the twer co entury: e comic, social and cultural. The economic dimension has been well-rehearsed th su sive crises from the mid1970s onwards undermining, first, the goal of full employ atm and hen stabilising retirement), and, second, the fiscal basis of the welfare state (accel ated with the ons et of a privatisation from the 1980s onwards) (Estes, 2001).

However we are neither a provident state and a providng state. The dialectic of risk and social insurance systems of calculation have failo uress or predict the increase in longevity, the blurring of the life-course and th ing trend for smaller families. What we are beginning to see occur with entry and immersio ip con society is the fracturing of insurance social systems that have failed to malra accurat predietions in the EU (Powell and Phillipson, 2004). This has led for those $\mathrm{w}^{1} \sim \mathrm{ca}$ afford invest in various insurance policies ways of minimizing risk that may befall in imes, wben illness occurs, unemployment (i.e: mortgage

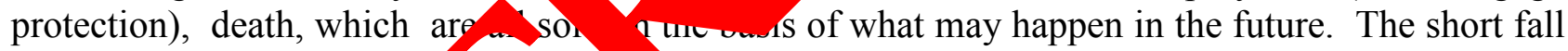
of this is that elders from ower soch conomic groups who without insurance will be caught within the widening fra uro spearing i the welfare state. Old age is also being changed by what Beck (1992) describ the of reflexive modernization. This may be conceived in terms of how individuals ar thelay public ert control and influence on the shape and character of Europe.

6.

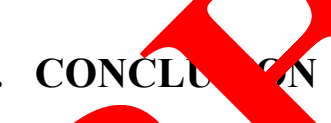

we do old age"? Is it a stage in life defined by a particular age or event such as retire t, is $\mathrm{t}$ determ ned by physical characteristics and the loss of independence, or is it an artifact ctures? Indeed, is it helpful to categorize people as being "old" at all, as opposed to ing "disadvantaged" or "dependent"? It may be inaccurate to expect older people to see themselv as a category with particular health needs and wants.Hence, the key task is to analyse the interplay between social policy and the lives of individuals, families or groups and communities. The expectation of negative events in the future and the different ways of how to respond to such expectations is central for the sociological approach to risk and uncertainty (Zinn 2004). Part of this reflexive response is the importance of recognising self-subjective dimensions of emotions, trust, biographical knowledge and resources (Zinn 2005) that impinge on the existential shaping old age. Hence, our discussion provides a critical narrative to the importance to the study of old age and welfarism in America and Europe. It has become commonplace for academics and practitioners to explore, develop and apply an assortment of social science perspectives on risk. In a post 9/11 world, questions around risk and risk management have become ever more pertinent, leading to reflections on a number of different levels about 'ontological security'. We are left with 
two questions: how do older people manage their sense of well being in a world in which less and less can be taken for granted? To what extent does the spectre of global risks interplay with more routine insecurities which reach to the capillary texture of day-to-day life of older people? There is an urgency to reflect on these questions to understand the subject positioning of older people in American and European societies that are characterised by increasing uncertainty.

\section{References}

[1] Adam, B,. Beck, U., and Joost Van, L (2002), The Risk Society and Beyond: Critical Issues for Social Theory, London: Sage.

[2] Adams, J (1995), Risk. London: UCL Press.

[3] Arber, S. and Attias-Donfut C., 2000: The Myth of Generational Cor 1ict. D lon: Routledge.

[4] Baker, T. / Simon, J. 2002: Embracing Risk. S. 1-32 in: Baker, Tom Jorathan non Ag.): Embracing risk: the changing culture of insurance and responsibili chis oo: Un sity of Chicago Press.

[5] Bauman, Z., 1992: Intimations of Postmodernity. London: P utledge \& gar Paul.

[6] Beck, U. (1986), Riskogesellschaft: Auf dem Weg ir eine dere Mojerne. Franfurt am Main: Suhrkamp Verlag.

[7] Beck, U. (1992b), Risk Society: Towards a New Modernity, Londor: Sage.

[8] Beck, U. (1994), The Reinvention of Polls: Towa ds a Theory of Reflexive Modernization in U. Beck, A. Giddens and S. hh, Re lexive Modernisation: Politics, Tradition and Aesthetics in the Modern $S$ - 1 Order. cuntoridge Polity Press.

[9] Beck, U. (1995), Ecological Politics in th Ag on, Cambridge: Polity Press.

[10] Beck, U. (1996), 'Risk Society the P1 vident State', in S. Lash, B. Szerzynski and B. Wynne (eds), Risk Environy nt an Modern y: Towards a new Ecology. London, Sage.

[11] Beck, U., Giddens, A., a La Reflexive Modernisation: Politics, Tradition and Aesthetics in the Mod on Social er. Cambridge Polity Press.

[12] Beck, U. (2001) y orld k Society, London: Polity Press.

[13] Best, F., 1980. Frexible Lito beduling. New York: Praeger.

[14] Bonss, y 995. Nm Risiko: Unsicherheit und Ungewissheit in der Moderne. Hamburg: Hamburger on.

[15] B 195, 1997. gesellschaftliche Konstruktion von Sicherheit. S. 21-41 in: Lippert, E., Prüf it und 9. Wachtler (Eds.): Sicherheit in der unsicheren Gesellscahft. Opladen: Wh Jerlag.

[16] Bonss, YZinn, J. 2005: Erwartbarkeit, Glück und Vertrauen - Zum Wandel biographischer Sicherhertskonstruktionen in der Moderne, Soziale Welt, 56(2/3):79-98.

[17] Castel, R. (1991), From Dangerousness to Risk in G. Burchell, C. Gordon and P. Miller (eds), The Foucault Effect: Studies in Governmentality. London: Harvester / Wheatsheaf: 281-298.

[18] Caplan, P. (eds) (2000), Risk Revisited, London: Pluto Press.

[19] Caplan, P. (2000), Risk Revisited - Introduction in P. Caplan (eds) Risk Revisited, London: Pluto Press.

[20] Caplan, P. (2000), 'Eating British Beef with Confidence': A Consideration of Consumers', Responses to BSE in Britain', in P. Caplan (eds) Risk Revisited, London: Pluto Press. 
[21] Douglas, M. and Wildavsky, A. (1983), Risk and Culture. Berkeley: University of California Press.

[22] Estes, C. and Associates, 2001: Social Policy and Aging. Thousand Oaks: Sage Books.

[23] Ewald, F. (1993), Two infinities of risk in B. Massumi (eds), The Politics of Everyday Fear. Minneapolis, Minnesota: University of Minnesota Press.

[24] Giddens, A., 1990: The Consequences of Modernity. Oxford: Polity Press.

[25] Giddens, A. (1991), Modernity and Self-Identity: Self and Society in the Late-Modern Age. Cambridge: Polity.

[26] Giddens,A. (1998) The Third Way; The Renewal of Social democracy Cambrity Press.

[27] Gilleard, C., and Higgs, P., 2000: Cultures of Ageing: self, citizen and tho dy. Lor on: Prentice-Hall.

[28] Kasperson, R. E. (2005): Introduction and Overview. In: J. Kasp on a R. E Kasperson,.: The Social Contours of Risk. Volume I: Public Ris ommun tion \& the Social Amplification of Risk. London - Sterling, VA: Earths an, pp. 1-

[29] Klein, N (2001 ), No Logo in a Branded World. New Y k, K ingo Pre, s.

[30] Krohn, W. and Krücken, G. (1993) Riskante T/mogien: Gexion und Regulation.
Frankfurt a. M.: Suhrkamp.

[31] Latour, B. and Woolgar, S. (1986): Laborator life: the c/nstruction of scientific facts. Princeton, N.J: Princeton University Press.

[32] Latour, B, (1993): We have never been m Cambriage, Mass: Harvard University Press.

[33] Leonard, P., 1997: Postmodern Welfare. L nd on: is se.

[34] Loewenstein, G., E. Weber, o. ee, N. Velch, 2001: Risks as feelings, Psychological Bulletin, 127(2):267-86.

[35] Lowe, R., 1993: The W e sucm since 1945. London: Macmillan.

[36] Luhmann, N., 1989 ogical Co Anication. Chicago: University of Chicago Press.

[37] Luhmann, N., 19 Risk. Sociological Theory. Berlin / New York: de Gruyter.

[38] Lupton, D 1999), Risk, Long on: Routledge.

[39] Luhmann, 193), R k: A Sociological Theory. New York: Aldine de Gruyter.

[40] Rer (19) Caims to Expert Knowledge and the Subversion of Democracy: The iump of Risk 9 er Uncertainty in Economy and Society, 25 (2), 222-54.

[41] Mà col, J., 998: The Politics of Retirement in Britain, 1878-1948. Cambridge: Cambridge Unive veress.

[42] Otway, 14., B. Wynne, 1989: Risk Communication: Paradigm and Paradox, Risk Analysis, 9, p. 141-145.

[43] Phillipson, C., 1998: The social construction of retirement: perspectives from critical theory and political economy. In M. Minkler and C. Estes, Critical Gerontology: Perspectives from Political and Moral Economy. New York: Baywood.

[44] Phillipson, C. and Powell, J L. 2004. 'Risk, Social Welfare and Old Age' article in Tulle, E (Ed.) Old Age and Human Agency, Nova Science Publishers

[45] Powell, J.L (2005) Social Theory and Aging, Rowman and Littlefield: New York 
[46] Powell, Jason L. and Wahidin, A 2004. 'Corporate Crime, Aging and Pensions in Great Britain', Journal of Societal and Social Policy, 3, 1, 37-55

[47] Slovic, P, (1999): Trust, Emotion, Sex, Politics, and Science: Surveying the Risk-Assessment Battlefield, Risk Analysis, 19(4):689-701.

[48] Slovic, P; Finucane, M; Peters, E; MacGregor, D (2002): Risk as analysis and risk as feelings. Some thoughts about affect, reason, risk, and rationality. (Annual Meeting of the Society for Risk Analysis, New Orleans, Louisiana, December 10, 2002)

[49] Stearns, P., 1977: Old Age in European Society: The Cast of France. London: Croom Helm.

[50] Thane, P., 2000: Old Age in English History: Past Experiences, Present Issues Oxford: Oxford University Press.

[51] Townsend, P. and Wedderburn D., 1965: The Aged in the Welfare State. on: Bell.

[52] Townsend, P., 1981: The structured dependency of the elderly: the cr atron on cial $r$ slicy in the twentieth century, Ageing and Society, (1 (1): 5-28.

[53] Tversky, A. und D. Kahneman, (1974): Judement under uncr int cursitic and Biases, Science, 185:1127-1131.

[54] Tulloch, J. and Lupton, D. (2003), Risk and Everyday L

[55] Vincent, J., 1995: Inequality of Old Age. London:

[56] Vincent, J., 1999: Politics, Power and Old Age. F Ickingham: Open University Press.

[57] Virilio, P. (1983), Pure War, New York: Semio (e).

[58] Walker, A and Naegele (1999) The Polit of Old As arope, Milton Keynes: OUP

[59] Wynne, B., 1987: Risk Management and H zary waste. Berlin: Springer.

[60] Zinn, J. O. (2004): Health, Rir and U certainty in the Life Course: A Typology of Biographical Certainty Const actio Social veory \& Health, 2:199-221.

[61] Zinn, J. O. (2005): The b. gra - a better way to understand behaviour in health and illness? Health, Ri \& \& Soc 7(1):1-9.

[62] Zinn, J. O. and Ta Gooby, 2006: The challenge of (managing) new risks and uncertainties. I. Tay Gooby,. and J.O Zinn, (Eds.): Risk in Social Science. Oxford:

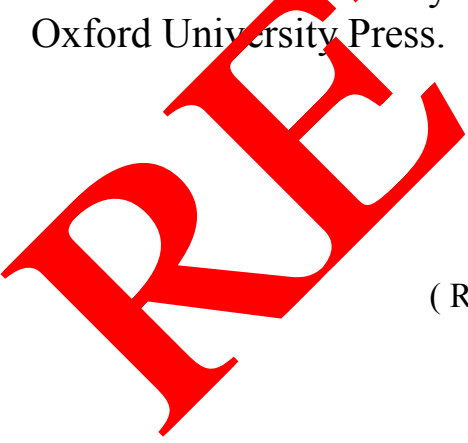

( Received 04 June 2015; accepted 18 June 2015 ) 